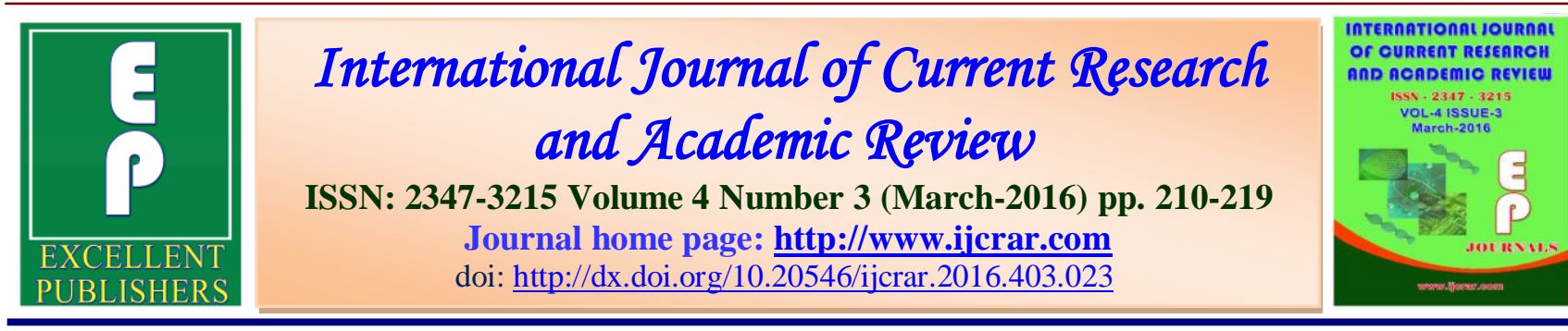

\title{
Effect of Alpha Lipoic Acid Supplementation on Nerve Conduction Velocity in Diabetic Neuropathy Patients - A Randomized Control Trial
}

\author{
Manish Bansal, P. K. Maheshwari, Varun Gupta* and Prabhat Agrawal \\ PG Department of Medicine, S N Medical College, Agra, India
}

*Corresponding author

KEYWORDS

Diabetic

neuropathy,

Alpha

lipoic acid,

$\mathrm{NCV}$

\section{A B S T T R A C T}

Diabetic peripheral neuropathy (DPN) is a common, symptomatic, long-term complication of diabetes mellitus. This study was undertaken to compare the efficacy and safety of alpha-lipoic acid supplementation in diabetic neuropathy patients. This was a prospective observational study. The patients were categorized into two groups, Group I included those patients who were prescribed alpha lipoic acid while group II patients received placebo irrespective of their antidiabetic treatment. Each patient was initially accessed and followed up at 12 weeks. Demographic details, presenting symptoms, history of diabetes, laboratory values pertaining to diabetes(Fasting blood sugar, Post prandial blood sugar and $\mathrm{HbA1c}$ ) were recorded. Nerve conduction velocity (NCV), Intensity of pain, using a visual analogue scale (VAS), diabetic neuropathy symptom (DNS) score and diabetic neuropathy examination (DNE) score, were assessed at baseline and then at 12 week follow-up. Data of 72 patients was analysed. There was statistically significant improvement in NCV, VAS, DNS and DNE score of the patients Results of this study suggest that treatment with Alpha Lipoic acid gives improvement in diabetic neuropathy. Although promising, further studies are needed to assess long-term treatment of ALA in large sample of population.

\section{Introduction}

Diabetic peripheral neuropathy (DPN) is a common, symptomatic, long-term complication of type 1 and 2 diabetes mellitus. It leads to a major physical disability, poor quality of life $^{1}$, high mortality $^{2}$, and an estimated total annual cost of $\$ 22$ billion $^{3}$. Mechanisms involved behind nerve damage are persistent hyperglycemia, microvascular insufficiency, oxidative stress, defective neurotrophism, and autoimmune nerve destruction.. Therefore, till date no effective treatment exists for DN, other than the control of hyperglycemia $^{4,5}$. Several drugs have been used with varying degree of success 
including antidepressants, anti-epileptics, $\alpha$ lipoic acid, baclofen, levodopa, methcobalamin, and bupropion. We conducted a randomized double-blind, placebo-controlled trial using oral Alpha lipoic acid $600 \mathrm{mg}$ per day treatment over 12 weeks period to study its effect and found promising results.

The aim of this study to study the effect of alpha lipoic acid supplementation on diabetic neuropathy through nerve conduction velocity test.

The main objectives of this study to evaluate the nerve conduction velocity in Type $2 \mathrm{DM}$ patients with neuropathy.

To compare the nerve conduction velocity in Type 2 DM patients with neuropathy after alpha lipoic acid supplementation with nerve conduction velocity in Type 2 DM patients with neuropathy after giving placebo.

\section{Materials and Methods}

This study was carried out in PG Department of Medicine Sarojini Naidu Medical College, Agra in on diabetics attending indoor and outdoor clinics. The study was conducted over a period of 18 months from March 2014.

\section{Study Design}

Study design was randomized doubleblinded controlled trial.

Baseline NCV was performed.

Patients were divided into two groupsGroup A received alpha lipoic acid supplementation and Group B received placebo.

Alpha lipoic acid supplementation was given in dose of $600 \mathrm{mg}$ daily oral for 12 weeks.
After 12 weeks NCV was repeated.

NCV of supplemented group and placebo receiving group was compared.

\section{Inclusion Criteria}

A case of diabetes mellitus (known case or recently detected) with sign or symptoms suggestive of diabetic neuropathy.

\section{Exclusion Criteria}

Patient having any other diseases known to cause peripheral neuropathy like chronic renal failure, liver failure, hypothyroidism, leprosy, porphyria etc.

Myopathy.

Presence of foot ulcers.

Patient on drugs known to cause peripheral neuropathy like isoniazid and phenytoin.

Overt diabetic retinopathy/blindness from any cause.

After dropouts both the study group and control group were having 36 patients each and hence data of total 72 patients was analysed. Out of these 72 cases, 38 were taking oral hypoglycemic drugs, 10 were on insulin and 24 were taking both and these were randomly distributed in both groups. Alpha lipoic acid was given to study group.

\section{Results and Discussion}

Burning, aching pain or tenderness and pricking sensation were found in maximum number of patients as shown in Table 1 and Bar diagram 1 below.

Loss of vibration sense, loss of deep sensation followed by loss or diminished reflexes are the most common findings seen 
in patients with Diabetes mellitus in both study group and control group as shown in Table 2 and Bar diagram below:

The symptoms of hyposthesia, paresthesia, cramp and pain shows stastistically significant improvement in the study group. In the control group, there was no significant change as shown by Table 3 and Bar diagram 3 below

This table shows statistically significant improvement in vibration sense loss, position sense loss, diminished or lost reflexes in study group.

In this table, the mean NCV of right and left CPN after 12 weeks follow up, increased

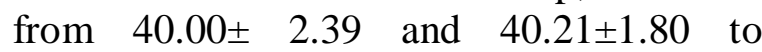
$49.75 \pm 2.15$ and $49.92 \pm 1.90$ in study group. There was no statistically significant improvement in control group.

The mean NCV of right and left median nerve after 12 weeks follow up increased from $42.40 \pm 2.18$ and $41.27 \pm 1.35$ to $51.16 \pm$ 2.14 and $50.83 \pm 1.36$ in study group which was statistically significant.

There was statistically significant improvement in VAS in study group as shown by Table 7 and bar diagram 7 .

ALA(Alpha lipoic acid) was first used therapeutically in Germany to treat diabetic neuropathy, there have been various controlled clinical trials assessing the efficacy of ALA in treating diabetic neuropathy. The findings of ALADIN study ${ }^{6}$ substantiated that i.v. treatment with ALA using a dose of $600 \mathrm{mg} /$ day over 3 weeks was superior to placebo in reducing symptoms of DPN. Following this shortterm trial with ALA, a long-term response was investigated in the ALADIN II trial ${ }^{7}$. In this trial Type 1 and 2 diabetic patients with symptomatic polyneuropathy were randomly assigned to three treatment regimens: i) $1200 \mathrm{mg}$ ALA; ii) $600 \mathrm{mg}$ ALA; and iii) placebo. ALA of 1200 or $600 \mathrm{mg}$ or placebo was i.v. administered once daily for five consecutive days before enrolling the patients in the oral treatment phase of 2 years. In this trial, a beneficial and statistically significant effect of ALA on several attributes of nerve conduction was observed after 2 years of treatment. The ALADIN III study ${ }^{8}$ showed that a 3 -week i.v. treatment with ALA followed by a 6month oral treatment could not demonstrate a prior specified effect on neuropathic symptoms, but it indicated some clinically meaningful effects on neuropathic deficits in the treatment of ALA. However, the Oral Pilot (ORPIL) study ${ }^{9}$, although with a smaller population, showed that oral treatment with $600 \mathrm{mg}$ ALA t.i.d. for 3 weeks might improve symptoms and deficits resulting from polyneuropathy in type 2 diabetic patients. In the SYDNEY trial ${ }^{10}$, diabetic patients were randomized to a parallel, double-blinded study of ALA (600 $\mathrm{mg}$ ) or placebo and infused daily i.v. for 5 days per week for a total of 14 treatments. It appears to show an unequivocal and large beneficial effect of i.v. racemic ALA on the frequency and severity of the positive neuropathic sensory symptoms due to diabetic polyneuropathy. It was of particular interest that no significant adverse reactions in association with ALA were observed in the treatment of the above studies. The SYDNEY II trial ${ }^{11}$ was a four-arm, parallel group, randomized, double-blind, placebocontrolled, multicenter trial using three oral doses of ALA (600, 1200, and $1800 \mathrm{mg}$ q.d.) over 5 weeks after a 1-week placebo run-in period. The results of the SYDNEY II trial demonstrated that oral treatment with ALA over 5 weeks improved the positive sensory symptoms scored by the TSS in diabetic patients with distal symmetric 
polyneuropathy. It was notable that this overall effect was not dose dependent, as there were no differences in the changes in mean TSS among all active groups.

The safety analysis revealed an overall favorable safety profile for the low dose. At higher oral doses, the rates of the gastrointestinal side effects were higher. The most frequent adverse event was a dosedependent increase in the incidence of nausea. In summary, in the absence of a dose response and because the higher doses resulted in increased rates of gastrointestinal side effects, the results of SYDNEY II trial revealed that an oral dose of $600 \mathrm{mg}$ once daily appeared to provide the optimum riskbenefit ratio.

Table.1 Duration of Diabetes Mellitus and Symptoms of Sensory and Motor Neuropathy (DNS-

Diabetic Neuropathy Symptom Score) at Initial Assesment

\begin{tabular}{|c|c|c|c|c|c|c|c|c|c|}
\hline \multirow{3}{*}{$\begin{array}{l}\text { Sympto } \\
\text { ms }\end{array}$} & \multirow{3}{*}{\begin{tabular}{|l} 
Duratio \\
n of \\
Diabete \\
s(years)
\end{tabular}} & \multicolumn{8}{|c|}{ Number of patients } \\
\hline & & \multicolumn{4}{|c|}{ Study $\operatorname{group}(n=36)$} & \multicolumn{4}{|c|}{ Control group $(n=36)$} \\
\hline & & $0-5$ & 6-10 & 11-15 & $16-20$ & $0-5$ & $6-10$ & 11-15 & $16-20$ \\
\hline \multicolumn{2}{|c|}{$\begin{array}{l}\text { Prickling } \\
\text { sensations }\end{array}$} & $\begin{array}{c}2 \\
(5.56)\end{array}$ & $\begin{array}{c}8 \\
(22.22)\end{array}$ & $\begin{array}{c}14 \\
(38.89)\end{array}$ & $\begin{array}{c}4 \\
(11.11)\end{array}$ & $\begin{array}{c}3 \\
(8.33) \\
\end{array}$ & $\begin{array}{c}2 \\
(5.56)\end{array}$ & $\begin{array}{c}12 \\
(33.33)\end{array}$ & $\begin{array}{c}4 \\
(11.11)\end{array}$ \\
\hline \multicolumn{2}{|c|}{ Numbness } & $\begin{array}{c}2 \\
(5.56)\end{array}$ & $\begin{array}{c}7 \\
(19.44) \\
\end{array}$ & $\begin{array}{c}14 \\
(38.89)\end{array}$ & $\begin{array}{c}4 \\
(11.11)\end{array}$ & $\begin{array}{c}1 \\
(2.78)\end{array}$ & $\begin{array}{c}3 \\
(8.33)\end{array}$ & $\begin{array}{c}12 \\
(33.33)\end{array}$ & $\begin{array}{c}4 \\
(11.11)\end{array}$ \\
\hline \multicolumn{2}{|c|}{$\begin{array}{l}\text { Burning, aching } \\
\text { pain or tenderness }\end{array}$} & $\begin{array}{c}4 \\
(11.11)\end{array}$ & $\begin{array}{c}7 \\
(19.44)\end{array}$ & $\begin{array}{c}14 \\
(38.89)\end{array}$ & $\begin{array}{c}6 \\
(16.67)\end{array}$ & $\begin{array}{c}2 \\
(5.56)\end{array}$ & $\begin{array}{c}4 \\
(11.11)\end{array}$ & $\begin{array}{c}12 \\
(33.33)\end{array}$ & $\begin{array}{c}6 \\
(16.67)\end{array}$ \\
\hline \multicolumn{2}{|c|}{$\begin{array}{l}\text { Unsteadiness in } \\
\text { walking }\end{array}$} & $\begin{array}{c}1 \\
(2.78)\end{array}$ & $\begin{array}{c}2 \\
(5.56)\end{array}$ & $\begin{array}{c}8 \\
(22.22) \\
\end{array}$ & $\begin{array}{c}6 \\
(16.67)\end{array}$ & $\begin{array}{c}1 \\
(2.78)\end{array}$ & $\begin{array}{c}2 \\
(5.56)\end{array}$ & $\begin{array}{c}8 \\
(22.22)\end{array}$ & $\begin{array}{c}6 \\
(16.67) \\
\end{array}$ \\
\hline
\end{tabular}

(Figures in parentheses indicate percentage)

Table.2 Duration of Diabetes Mellitus and Signs of Sensory and Motor Neuropathy (DNEDiabetic Neuropathy Examination Score) at Initial Assesment

\begin{tabular}{|c|c|c|c|c|c|c|c|c|c|c|c|c|c|c|c|c|c|}
\hline \multirow{4}{*}{ Signs } & \multirow{4}{*}{$\begin{array}{l}\text { Duration of } \\
\text { Diabetes } \\
\text { Mellitus (yrs) }\end{array}$} & \multicolumn{16}{|c|}{ Number of patients } \\
\hline & & \multicolumn{8}{|c|}{ Study $\operatorname{group}(n=36)$} & \multicolumn{8}{|c|}{ Control $\operatorname{group}(n=36)$} \\
\hline & & \multicolumn{2}{|c|}{$0-5$} & \multicolumn{2}{|c|}{ 6-10 } & \multicolumn{2}{|c|}{ 11-15 } & \multicolumn{2}{|c|}{ 16-20 } & \multicolumn{2}{|c|}{$0-5$} & \multicolumn{2}{|c|}{ 6-10 } & \multicolumn{2}{|c|}{ 11-15 } & \multicolumn{2}{|c|}{ 16-20 } \\
\hline & & No. & $\%$ & No. & $\%$ & No & $\%$ & No & $\%$ & No & $\%$ & No & $\%$ & No & $\%$ & No. & $\%$ \\
\hline \multicolumn{2}{|c|}{ Muscle strength } & 0 & 0.0 & 2 & 5.6 & 5 & 13.9 & 4 & 11.1 & 0 & 0.0 & 1 & 4.8 & 5 & 13.9 & 5 & 13.9 \\
\hline \multicolumn{2}{|c|}{$\begin{array}{l}\text { Index finger: Sensitivity to } \\
\text { pinpricks }\end{array}$} & 1 & 2.8 & 8 & 22.2 & 14 & 38.9 & 5 & 13.9 & 1 & 2.8 & 4 & 11.1 & 12 & 33.3 & 4 & 11.1 \\
\hline \multicolumn{2}{|c|}{$\begin{array}{l}\text { Big toe: Sensitivity to } \\
\text { pinpricks, Sensitivity to } \\
\text { touch, Vibration perception, } \\
\text { Sensitivity to joint position }\end{array}$} & 2 & 5.6 & 8 & 22.2 & 14 & 38.9 & 6 & 16.7 & 2 & 5.6 & 4 & 11.1 & 12 & 33.3 & 4 & 11.1 \\
\hline \multicolumn{2}{|c|}{ Reflexes lost or diminished } & 2 & 5.6 & 4 & 11.1 & 12 & 33.3 & 6 & 16.7 & 2 & 5.6 & 4 & 11.1 & 12 & 33.3 & 4 & 11.1 \\
\hline
\end{tabular}


Int.J.Curr.Res.Aca.Rev.2016; 4(3): 210-219

Table.3 Symptoms of Sensory \& Motor Neuropathy(DNS) After Alpha Lipoic Acid Administration in Study Group as Compared to Control Group

\begin{tabular}{|l|c|c|c|c|c|c|c|c|c|c|}
\hline \multirow{2}{*}{ Symptoms } & \multicolumn{4}{|c|}{ Study group(n=36) } & \multicolumn{4}{c|}{ Control group(n=36) } \\
\cline { 2 - 12 } & Initial & follow up & \% change & \multicolumn{2}{c|}{ Initial } & \multicolumn{1}{|c|}{ follow up } & $\%$ change \\
\hline & No. & $\%$ & No. & $\%$ & & No. & $\%$ & No. & $\%$ & \\
\hline Prickling sensations & 28 & 77.78 & 10 & 27.78 & 64.29 & 21 & 58.33 & 23 & 63.89 & -9.52 \\
\hline Numbness & 27 & 75.00 & 11 & 30.56 & 59.26 & 20 & 55.56 & 22 & 61.11 & -10.00 \\
\hline $\begin{array}{l}\text { Burning aching pain or } \\
\text { tenderness }\end{array}$ & 31 & 86.11 & 15 & 41.67 & 51.60 & 24 & 66.66 & 23 & 63.89 & 4.1 \\
\hline Unsteadiness in walking & 17 & 47.22 & 9 & 25.00 & 47.05 & 17 & 47.22 & 17 & 47.22 & 0 \\
\hline
\end{tabular}

*The groups are significantly different.

NS- The groups are not significantly different Single Factor Anova is used

Table.4 Signs of Sensory and Motor Neuropathy(DNE) After Alpha Lipoic Acid Administration in Study Group as Compared to Control Group

\begin{tabular}{|c|c|c|c|c|c|c|c|c|c|c|}
\hline \multirow[t]{3}{*}{ Symptoms } & \multicolumn{5}{|c|}{ Study group $(n=36)$} & \multicolumn{5}{|c|}{ Control $\operatorname{group}(n=36)$} \\
\hline & \multicolumn{2}{|c|}{ Initial } & \multicolumn{2}{|c|}{ follow up } & \multirow{2}{*}{$\begin{array}{c}\% \\
\text { chang } \\
\mathrm{e}\end{array}$} & \multicolumn{2}{|c|}{ initial } & \multicolumn{2}{|c|}{ follow up } & \multirow{2}{*}{$\begin{array}{c}\% \\
\text { chan } \\
\text { ge } \\
\end{array}$} \\
\hline & No. & $\%$ & No. & $\%$ & & No. & $\%$ & No. & $\%$ & \\
\hline Muscle strength & 11 & 30.56 & 6 & 16.67 & 45.45 & 11 & 30.56 & 11 & 30.56 & 0.00 \\
\hline $\begin{array}{l}\text { Index finger: Sensitivity to } \\
\text { pinpricks }\end{array}$ & 28 & 77.78 & 12 & 33.33 & 57.14 & 21 & 58.33 & 23 & 63.89 & -9.52 \\
\hline $\begin{array}{l}\text { Big toe: Sensitivity to } \\
\text { pinpricks, Sensitivity to } \\
\text { touch, Vibration perception, } \\
\text { Sensitivity to joint position }\end{array}$ & 30 & 83.33 & 12 & 33.33 & 60.00 & 22 & 61.11 & 23 & 63.89 & -4.55 \\
\hline reflexes lost or diminished & 24 & 66.67 & 10 & 27.78 & 58.33 & 22 & 61.11 & 23 & 63.89 & -4.55 \\
\hline & & $\mathrm{p}$ value & $=0.0$ & 25748 & & & $\mathrm{p}$ val & $=0.8$ & $1881^{1}$ & \\
\hline
\end{tabular}

*The groups are significantly different.

$N S$ - The groups are not significantly different

Table.5 Effect of Alpha Lipoic Acid Supplementation on Nerve Conduction Velocity in Right and Left Common Peroneal Nerve(CPN) in Diabetes Mellitus Patients

\begin{tabular}{|c|c|c|c|c|c|c|c|c|c|}
\hline & & \multicolumn{4}{|c|}{ Study group $(n=36)$} & \multicolumn{4}{|c|}{ Control $\operatorname{group}(n=36)$} \\
\hline & & Initial & $\begin{array}{l}\text { follow } \\
\text { up }\end{array}$ & $\mathrm{t}$-value & $\mathrm{p}$ value & initia & $\begin{array}{l}\text { follow } \\
\text { up }\end{array}$ & $\begin{array}{l}\mathrm{t}- \\
\text { value }\end{array}$ & $\begin{array}{l}\mathrm{p} \\
\text { value }\end{array}$ \\
\hline \multirow{2}{*}{ Right C.P.N. } & Mean & 40.00 & 49.75 & \multirow[b]{2}{*}{-18.1974} & \multirow{2}{*}{$<0.0001$} & 40.51 & 40.61 & \multirow{2}{*}{$\begin{array}{l}- \\
0.1946\end{array}$} & \multirow[b]{2}{*}{0.8463} \\
\hline & SD & 2.39 & 2.15 & & & 2.21 & 2.15 & & \\
\hline \multirow{2}{*}{ Left C.P.N. } & Mean & 40.21 & 49.92 & \multirow{2}{*}{-22.26} & \multirow{2}{*}{$<0.0001$} & 40.39 & 40.74 & \multirow{2}{*}{ 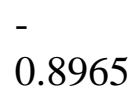 } & \multirow{2}{*}{0.3731} \\
\hline & SD & 1.80 & 1.90 & & & 1.72 & 1.59 & & \\
\hline
\end{tabular}


Int.J.Curr.Res.Aca.Rev.2016; 4(3): 210-219

Table.6 Effect of Alpha Lipoic Acid Supplementation on Nerve Conduction Velocity in Right and Left Median Nerve in Diabetes Mellitus Patients

\begin{tabular}{|c|c|c|c|c|c|c|c|c|c|c|}
\hline & & \multicolumn{4}{|c|}{ Study group $(n=36)$} & \multicolumn{4}{|c|}{ Control $\operatorname{group}(n=36)$} \\
\hline & & & initial & $\begin{array}{l}\text { follow } \\
\text { up }\end{array}$ & t- value & $\mathrm{p}$ value & $\begin{array}{l}\text { initia } \\
1\end{array}$ & $\begin{array}{l}\text { follow } \\
\text { up }\end{array}$ & $\mathrm{t}$ - value & $\mathrm{p}$ value \\
\hline \multirow{2}{*}{$\begin{array}{l}\text { Right } \\
\text { Nerve }\end{array}$} & \multirow{2}{*}{ Median } & $\begin{array}{l}\text { Mea } \\
n\end{array}$ & 42.40 & 51.16 & \multirow[t]{2}{*}{-17.2055} & \multirow[t]{2}{*}{$<0.0001$} & $\begin{array}{l}42.3 \\
1\end{array}$ & 41.99 & \multirow[t]{2}{*}{0.6833} & \multirow[t]{2}{*}{0.4967} \\
\hline & & SD & 2.18 & 2.14 & & & 2.07 & 1.90 & & \\
\hline \multirow{2}{*}{$\begin{array}{l}\text { Left } \\
\text { Nerve }\end{array}$} & \multirow{2}{*}{ Median } & $\begin{array}{l}\text { Mea } \\
n\end{array}$ & 41.27 & 50.83 & \multirow[t]{2}{*}{-29.9331} & \multirow[t]{2}{*}{$<0.0001$} & $\begin{array}{l}41.5 \\
8\end{array}$ & 41.89 & \multirow[t]{2}{*}{-0.7991} & \multirow[t]{2}{*}{0.427} \\
\hline & & SD & 1.35 & 1.36 & & & 1.70 & 1.59 & & \\
\hline
\end{tabular}

Bar Diagram.1

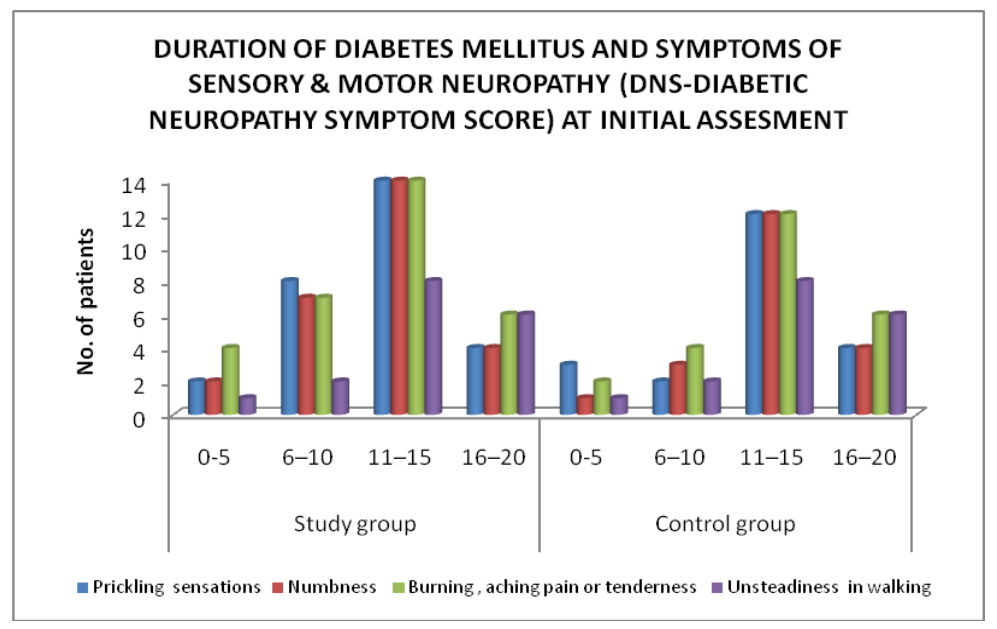

Bar Diagram.2

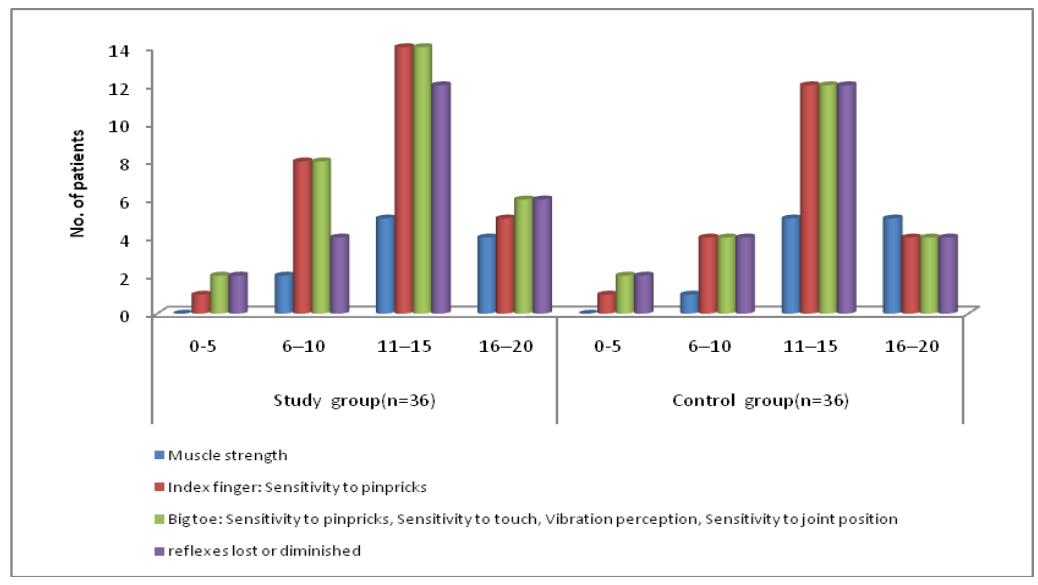


Int.J.Curr.Res.Aca.Rev.2016; 4(3): 210-219

\section{Bar Diagram.3}

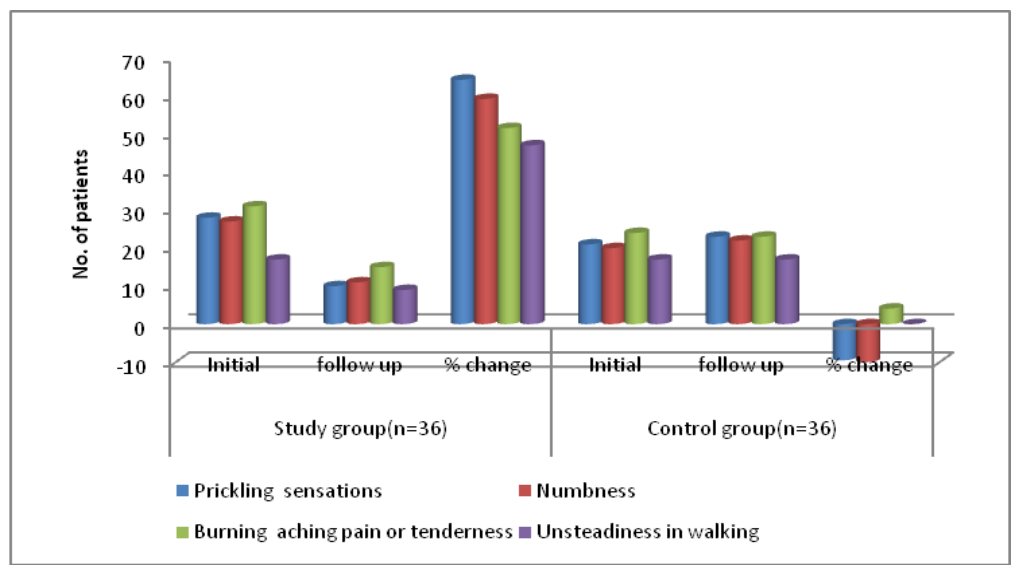

\section{Bar Diagram.4}

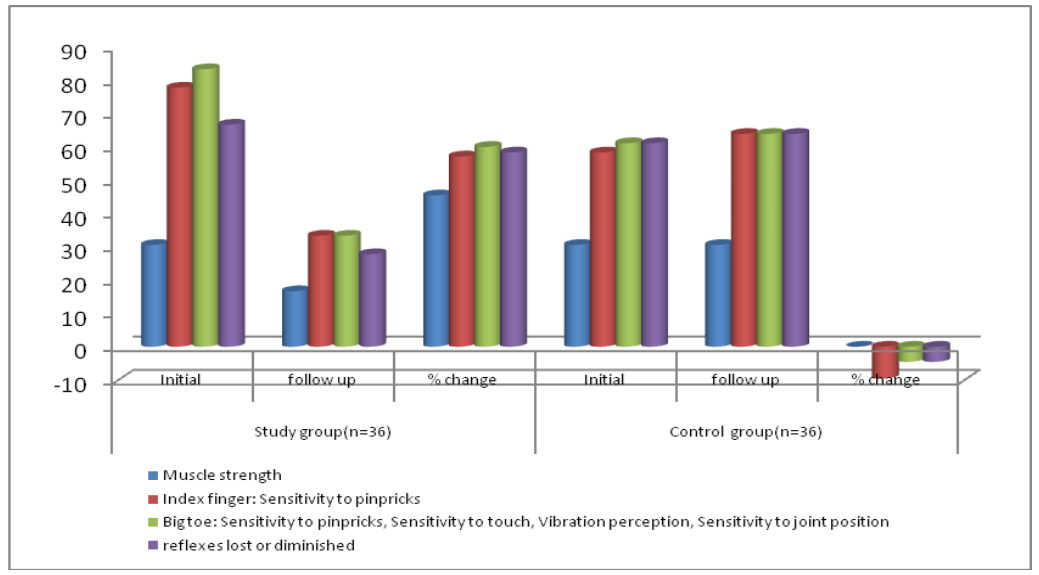

\section{Bar Diagram.5}

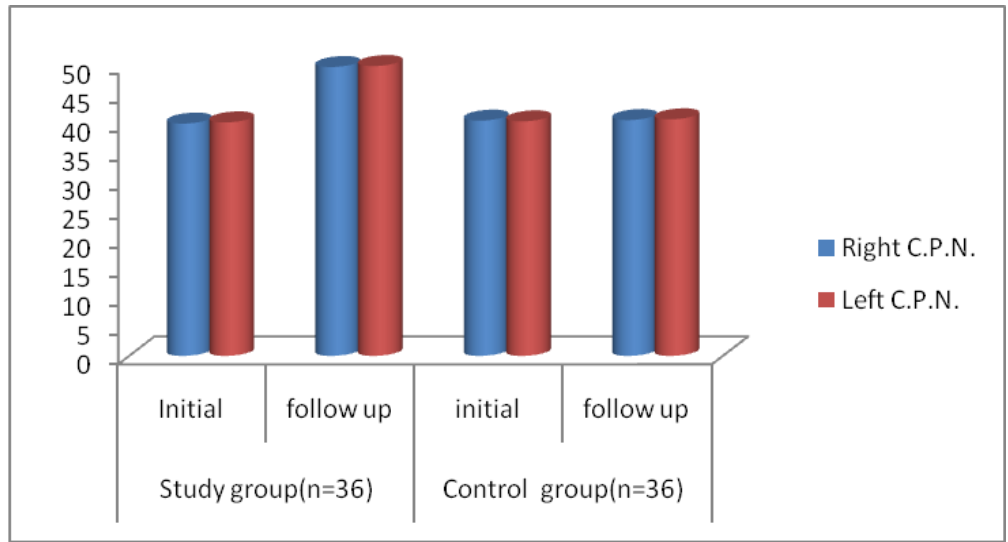


Int.J.Curr.Res.Aca.Rev.2016; 4(3): 210-219

Table.7 VAS (Visual Analogue Scale) at Initial Accessment and After Follow up in Study Group and Control Group

\begin{tabular}{|l|l|c|c|c|}
\hline \multirow{2}{*}{} & \multicolumn{2}{|c|}{ study group(n=36) } & \multicolumn{2}{c|}{ control group(n=36) } \\
\cline { 2 - 5 } & Initial & followup & No. & \% \\
\hline Mean & 5.64 & 2.50 & 5.69 & 5.44 \\
\hline SD & 1.74 & 1.00 & 1.79 & 1.50 \\
\hline t-value & 9.3877 & 0.6423 \\
\hline p-value & $<0.0001$ & 0.5228 \\
\hline
\end{tabular}

\section{Bar Diagram.6}

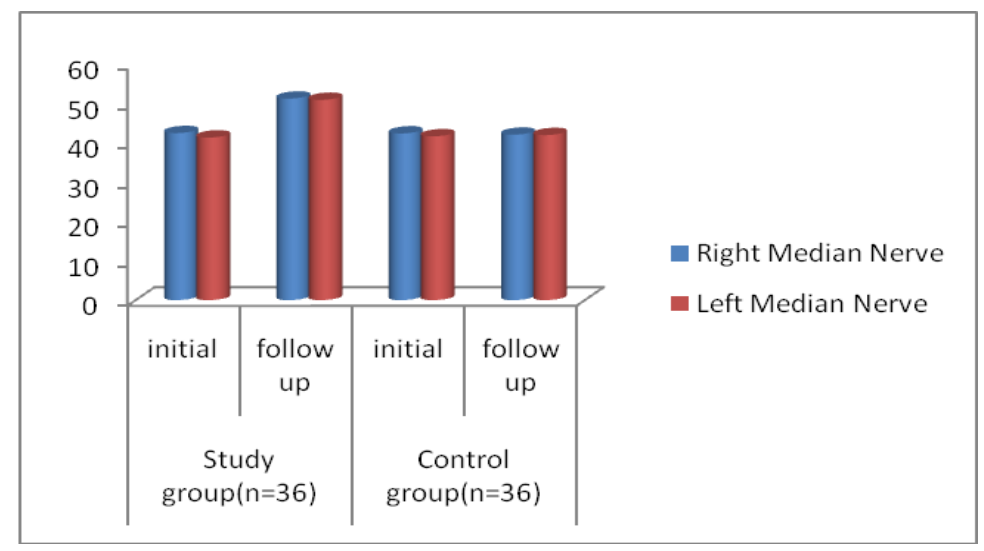

\section{Bar Diagram.7}

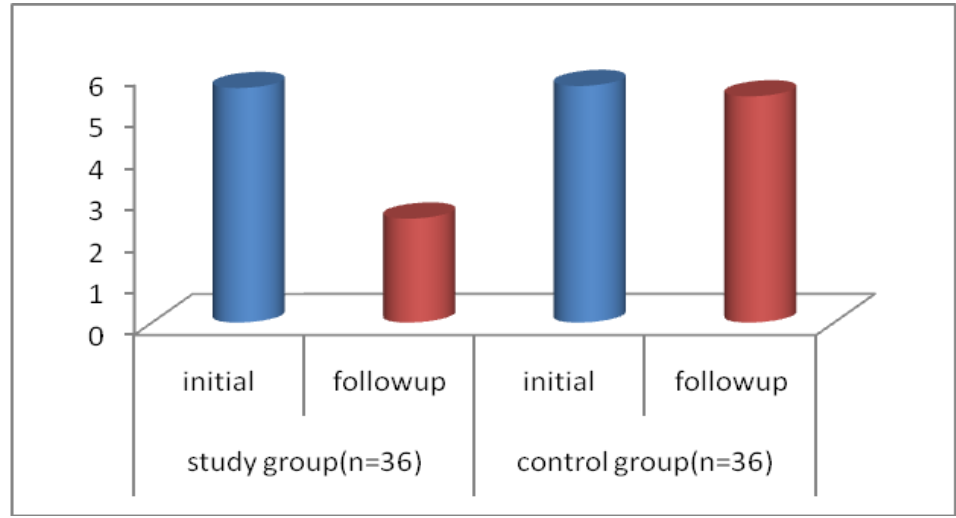

In our study, among 72 Diagnosed type 2 diabetic neuropathy patients, nerve conduction velocity was measured before and after treatment at 0 and 12 weeks. Total 72 cases of diabetic neuropathic patients were subdivided into two groups. Group I consists of the patients of diabetic neuropathy receiving alpha lipoic acid and group II consists of the patient of diabetic neuropathy which were receiving placebo. Both groups were receiving their antidiabetic treatment as well. Patients were distributed according to different age starting from 40 years and according to sex. 
In both groups maximum number of patients were having age from 61-70 years.

From the study it was observed that diabetic neuropathy occurred maximally in the patients who had diabetes of about 11-15 years $(36.11 \%)$ or more.

In the peripheral neuropathy, maximum number of patients had loss of vibration sense $(72.22 \%)$, followed by muscle cramp and pain (72.20\%), hyposthesia (68.05\%), paresthesia $(68.00 \%)$, loss of position sense (54.66\%), diminished reflexes $(63.88 \%)$ and muscle weakness $(30.05 \%)$ (Table 1 and 2).

On analysis in study group, there was $64.29 \%$ improvement in pricking sensation, $59.26 \%$ improvement in numbness, $51.60 \%$ improvement in burning aching pain or tenderness, $47.05 \%$ improvement in unsteadiness in walking, $45.45 \%$ improvement in muscle strength, $57.14 \%$ improvement in sensitivity to pinprick sensation in index finger, 60\%improvement insensitivity to pinprick, touch, vibration, joint position sense, $58.33 \%$ improvement in reflexes (table 3 and 4). The nerve conduction velocity was improved in right and left CPN and Median nerve. In study group these parameters were improved and improvement was statistically significant(p value $<0.05$ ) (table 5 and 6 ). VAS mean value was significantly lowered in study group (table -7). Blood sugar level (fasting and post parandial) was improved in both group but serum cholesterol, SGOT, SGPT, serum creatinine level did not shown any significant improvement.

\section{Conclusion}

Alpha lipoic acid have beneficial effect in peripheral neuropathy, in the form of relief of subjective symptoms and signs and it has got significant effect in the form of improvement in nerve conduction velocity. Although promising, further studies are needed to assess long-term treatment of ALA given orally in an outpatient setting to assess its potential as a viable treatment option for patients with DSPN and its safety and toxicity profile.

\section{Acknowledgement}

I acknowledge the significant contribution of my coauthors and the contents of the manuscript are in agreement with each author mentioned.

\section{References}

1.Vileikyte L, Leventhal H, Gonzalez JS, Peyrot M, Rubin RR, Ulbrecht JS et al. Diabetic peripheral neuropathy and depressive symptoms- the association revisited. Diabetes Care 2005; 28:2378-2383.

2.Boulton AJ, Vinik AI, Arezzo JC, Bril V, Feldman EL, Freeman $\mathrm{R}$ et al.Diabetic neuropathies: a statement by the American Diabetes Association.Diabetes Care 2005; 28(9):56-62.

3.American diabetes association. Living with diabetes. High blood pressure (hypertension). Available from: http://www.diabetes.org/livingwithdiabetes/complications/high-bloodpressure-hypertension.html.

4.Ohkubo Y, Kishikawa H, Araki E, Miyata $\mathrm{T}$, Isami $\mathrm{S}$, Motoyoshi $\mathrm{S}$ et al. Intensive insulin therapy prevents the progression of diabetic microvascular complications in Japanese patients with non-insulindependent diabetes mellitus-a randomized prospective 6-year study. Diabetes Res Clin Pract 1995;28:103-117. 
5.Diabetes Control and Complications Trial Research Group: The effect of intensive treatment of diabetes on the development and progression of long-term complications in insulindependent diabetes mellitus. N Engl J Med 1993;329:977-986.

6.Ziegler D, Hanefeld M, Ruhnau KJ. (ALADIN Study).Diabetologia 1995;38:1425-1433.

7.Reljanovic M, Reichel G, Rett K. (ALADIN II). Alpha Lipoic Acid in Diabetic Neuropathy. Free Radic Res 1999;31:171-179.

8.Ziegler D., Hanefeld M., Ruhnau K. (ALADIN III Study). Diabetes Care 1999; 22:1296-1301
9.Ziegler D, Reljanovic M, Mehnert H, Gries FA.Experimental and Clinical Endocrinology \& Diabetes.Official Journal, German Society of Endocrinology and German Diabetes Association 1999; 107(7):421-430

10. Alexander S. Ametov, Alexei barinov, peter $\mathrm{j}$ dyck, robrt Hermann, Natalia kozlova, William j litchi. HeinrichHeine-Universität Düsseldorf, Düsseldorf, North Rhine-Westphalia. Germany Diabetes Care (Impact Factor: 8.42). 03/2003; 26(3):770-6. DOI: $10.2337 /$ diacare.26.3.770.

11. Ziegler D1, Ametov A, Barinov A, Dyck PJ, Gurieva I, Low PA et al.Diabetes Care 2006 Nov;29(11):2365-70.

\section{How to cite this article:}

Manish Bansal, P. K. Maheshwari, Varun Gupta and Prabhat Agrawal. 2016. Effect of Alpha Lipoic Acid Supplementation on Nerve Conduction Velocity in Diabetic Neuropathy Patients A Randomized Control Trial. Int.J.Curr.Res.Aca.Rev. 4(3): 210-219. doi: http://dx.doi.org/10.20546/ijcrar.2016.403.023 